\title{
AKULTURASI PEMEROLEHAN KOMPETENSI PRAGMATIK ANAK USIA DINI PADA LINGKUNGAN KELUARGA ETNIK JAWA DI ERA REVOLUSI DIGITAL
}

\author{
${ }^{1}$ Saptono Hadi, ${ }^{2}$ Sri Utami \\ ${ }^{1,2}$ Universitas Nahdlatul Ulama Blitar \\ ${ }^{1}$ saptono656@gmail.com, ${ }^{2}$ utami3215@gmail.com

\begin{tabular}{l}
\hline Tersedia Online di \\
http://www.jurnal.unublitar.ac.id/ \\
index.php/briliant
\end{tabular} \\ Sejarah Artikel \\ Diterima pada 16 Desember \\ 2018 \\ Disetuji pada 28 Januari 2019 \\ Dipublikasikan pada 20 Februari \\ 2019 Hal. 35-45

\begin{tabular}{l}
\hline Kata Kunci: \\
\hline Akulturasi, Pragmatik, AUD \\
\hline DOI: \\
\hline http://dx.doi.org/10.28926/briliant \\
.v3i3.262 \\
\hline
\end{tabular}

\begin{abstract}
Abstrak: Revolusi digital merupakan perubahan dari teknologi mekanik dan elektronik analog ke teknologi digital. Bahasa merupakan hal pertama sekali yang dikuasai oleh anak, diperoleh secara alamiah melalui berbagai media di dalam lingkungan keluarga pengasuh anak tanpa melewati proses pembelajaran, berjalan secara spontan, tanpa sadar, dan tanpa beban untuk memahami maupun dipahami orang lain. Tujuan penelitian ini adalah (1) mengkaji proses internal dalam pemerolehan pragmatik ber-BI anak usia dini dwibahasawan Jawa-Indonesia di era revolusi digital, dan (2) mengkaji faktor eksternal dalam pemerolehan pragmatik ber-BI anak usia dini dwibahasawan Jawa-Indonesia di era revolusi digital. Ancangan teori yang digunakan dalam penelitian ini adalah teori pragmatik (Lavinson, 1992) dan teori psikolinguistik, khususnya teori pemerolehan bahasa, yaitu teori konstruksi kreatif (Dulay, Burt, dan Krashen, 1982), rancangan penelitian silang (cross sectional), subjek dengan usia beda yaitu anak usia dini usia 2, 3, 4 tahun. Analisis data dengan teknik
\end{abstract} \\ analisis diskursif. Hasil penelitian menunjukkan adanya proses konstruksi kreatif dalam \\ pemerolehan pragmatik pada anak usia dini dwibahasawan Jawa-Indonesia di era digital yang \\ meliputi (1) pola dominasi sosial-budaya dalam pemerolehan pragmatik ber-BI, (2) strategi \\ interaksi, dan motivasi dan keluwesan ego penutur dalam pemerolehan kompetensi pragmatik \\ ber-BI anak usia usia dini di era revolusi digital dalam lingkungan keluarga enik Jawa.
}

\section{PENDAHULUAN}

Bahasa merupakan hal pertama sekali yang dikuasai oleh anak, diperoleh secara alamiah melalui berbagai media di dalam lingkungan keluarga pengasuh anak tanpa melewati proses pembelajaran. Bahasa berjalan secara spontan, tanpa sadar, dan tanpa beban, terjadi secara langsung dalam situasi informal tanpa melalui pembelajaran formal, didorong oleh kebutuhan baik untuk memahami maupun dipahami orang lain. Pemerolehan bahasa berlangsung secara terusmenerus dalam konteks berbahasa yang nyata dan bermakna, diperoleh secara lisan melalui tindak berbahasa maupun media.

Saryono (2010:78) mengatakan bahwa proses PBK merupakan proses konstruksi kreatif atau pembentukan dan pengujian hipotesis tentang kaidah bahasa kedua yang dipelajari, bukan proses pembentukan kebiasaan dan penubian (drill). Proses ini berlangsung dengan dikendalikan oleh mekanisme mentalis yang disebut LAD atau pengorganisasi, bukan lingkungan atau situasional. Adanya kekreatifan menyebabkan pembelajar melakukan proses konstruksi kreatif dalam memperoleh B2. Iskandarwassid, (2013: 77-113) pemerolehan bahasa 
pertama (language acquisition) merupakan proses pemilikan kemampuan berbahasa secara alamiah. Proses ini memiliki karakteristik 1) berjalan secara spontan, tanpa sadar, dan tanpa beban, 2) terjadi secara langsung dalam situasi informal tanpa melalui pembelajaran formal, 3) didorong oleh kebutuhan baik untuk memahami maupun dipahami orang lain, 4) berlangsung secara terusmenerus dalam konteks berbahasa yang nyata dan bermakna, 5) diperoleh secara lisan melalui tindak berbahasa menyimak, mendengarkan dan berbicara melalui berbagai media.

\section{Anak di Era Digital}

Sangat cepatnya perkembangan teknologi informasi, menjadi dasar kajian utama sebagai tantangan penting dalam pendidikan anak di usia dini di era digital. Tantangan ini harus dihadapi para orang tua didik, dunia pendidikan khususnya para pendidik di tingkat Pendidikan Anak Usia Dini. Era digital merupakan kajian peristilahan yang digunakan pada kemunculan dunia digital, jaringan internet, atau lebih khusus lagi teknologi informasi yang ditandai adanya teknologi, yang mana proses tersebut terjadi peningkatan pada kecepatan dan arus pergantian pengetahuan dalam ekonomi dan kehidupan masyarakat. Tindak perilaku karakter tersebut berimplikasi pada performansi komunikatif yang merupakan bagian dari proses penggunaan aktual pengetahuan linguistik dan pengetahuan pragmatik dalam memahami dan memproduksi wacana dalam berkomunikasi.

Anak usia dini di era digital, dimungkinkan lebih banyak menghabiskan waktu dengan bermain game, sehingga lebih suka bermain sendiri, dan tidak lagi membutuhkan teman bermain, sehingga berdampak cukup kuat terhadap kemampuan pragmatik anak dalam berkomunikasi dengan lawan tutur (tindak tutur). Pemerolehan bahasa yang didapat melalui penggunaan gadget tanpa melalui pendampingan dan pengawasan yang dapat dilakukan oleh para orang tua, dalam menghadapi perilaku anak usia dini pada era digital akan mempengaruhi karakter kepribadian anak dalam melakukan tindak tutur.

\section{Pemerolehan B1 dan B2}

Tanuwijaya (2011:2.6), mendeskripsikan bahwa studi pemerolehan bahasa dibedakan antara pemerolehan B1 dan B2. Pemerolehan B1 mengacu pada proses penguasaan bahasa yang yang pertama kali dipelajari dan dikuasai oleh seorang anak. Adapun pemerolehan B2 mengacu pada proses penguasaan bahasa yang terjadi setelah seseorang memperoleh bahasa pertamanya atau bahasa ibunya. Jika seseorang anak menguasai BJ sebagai bahasa pertamanya kemudian belajar BI, maka BI adalah bahasa keduanya. BI dianggap sebagai B2 karena BI juga dipergunakan sebagai alat komunikasi di lingkungan anak.

Ditinjau dari bekerjanya alat pemerolehan bahasa, pada dasarnya proses pemerolehan B2 memiliki proses yang sama atau mirip dengan pemerolehan B1. Pertama, proses yang hampir sama antara pemerolehan B1 dan B2 ini ditandai oleh adanya strategi kognitif yang sama karena seseorang mengalami proses pemerolehan dengan cara yang sama. Kedua, dalam menghasilkan kalimatkalimat, baik pembelajar B1 maupun B2, lebih mudah mengingat kalimat-kalimat yang dapat mereka tafsirkan (pahami). Ketiga, pembelajar B1 dan B2 melakukan kesalahan yang sama dalam kategori linguistik yang sama (Dulay dan Burt, 1982). Keempat, dalam penelitian tentang konstruksi transisi (transitioneal construction) dikemukakan bahwa pembelajar B1 dan B2 mengalami tahap-tahap untuk memperoleh struktur tertentu yang sama (Tanuwijaya, 2011:2.17).

36 BRILIANT: Jurnal Riset dan Konseptual

Volume 4 Nomor 1, Februari 2019 


\section{Kompetensi Pragmatik}

Dalam kajian pemerolehan bahasa dibedakan antara konsep kompetensi dan performansi. Menurut Chomsky (Pateda, 1991:181), kompetensi adalah representasi mental kaidah bahasa yang merupakan tatabahasa internal penutur dan mitratutur. Tatabahasa ini bersifat implisit dan berada dalam intuisi tatabahasa kalimat penutur-pendengar. Adapun performansi merupakan penggunaan tatabahasa tersebut dalam memahami dan memproduksi bahasa. Bertolak dari pandangan tersebut, kajian pemerolehan bahasa cenderung terfokus pada penemuan realitas mental yang mendasari penggunaan bahasa dalam performansi secara aktual. Performansi dipandang sebagai bentuk transformasi kemampuan linguistik yang mendasarinya yang bebas dari stimulus yang berasal dari luar.

Lebih lanjut, Hymes memperluas pembedaan kompetensi dan performasi berkaitan dengan aspek komunikatif bahasa. Menurut Hymes yang didukung oleh kompetensi komunikatif meliputi pengetahuan penutur-pendengar yang merupakan ketepatan dan kelayakan baik perilaku bahasa yang benar maupun perilaku bahasa efektif dalam hubungannya dengan tujuan komunikasi. Performansi komunikatif merupakan penggunaan aktual pengetahuan linguistik dan pengetahuan pragmatik dalam memahami dan memproduksi wacana.

\section{Pemerolehan Kompetensi Pragmatik}

Pemerolehan kompetensi pragmatik BI anak usia dini dikaji dengan menggunakan ancangan teori konstruksi kreatif (Dulay, Burt, dan Krashen, 1982), Saryono (2010:78). Penggunaan ancangan ini didasari oleh pandangan bahwa proses pemerolehan bahasa anak merupakan proses yang melibatkan perangkat bawaan dalam otak dan proses pengalaman berbahasa yang dialami anak melalui kegiatan komunikasi di lingkungannya. Proses interaksi antara kemampuan bawaan dan pengalaman berbahasa ini menyebabkan terjadinya proses pemerolehan bahasa terjadi secara konstruktif. Proses konstruksi kreatif dalam pemerolehan bahasa ini terjadi secara bertahap berdasarkan ujaran yang didengar sebagai usaha untuk membentuk hipotesis-hipotesis tentang sistem bahasa yang diperoleh.

Dalam proses pemerolehan kompetensi pragmatik, sebagaimana yang terjadi pada permerolehan aspek kebahasaan lainnya, juga terdapat konstruksi transisi, yaitu penggunaan struktur tertentu yang secara berangsur-angsur mengalami perkembangan selama proses pemerolehan berlangsung. Konstruksi transisi, bahasa antara (interlanguge), yaitu ujaran anak yang tidak sama dengan ujaran orang dewasa atau penutur asli dalam mengungkapan makna yang sama. Ujaran anak yang merupakan interlanguage ini adalah hasil proses pembentukan hipotesis yang menghasilkan kaidah (norma) kebahasaan yang berbeda dengan kaidah kebahasaan bahasa target.

\section{Strategi Pemerolehan Kompetensi Pragmatik}

Teori pemerolehan bahasa yang digunakan sebagai piranti untuk memahami pemerolehan kompetensi pragmatik anak bertolak dari teori interaksionisme yang memandang bahwa faktor bawaan dan faktor lingkungan berperan penting dalam pemerolehan bahasa. Berdasarkan teori ini penguasaan bahasa anak usia dini terjadi karena adanya interaksi antara faktor eksternal dan faktor internal yang dimiliki anak. Sejalan dengan tujuan, maka faktor eksternal penutur yang dikaji dalam penelitianberkaitan dengan faktor lingkungan, khususnya masukan dalam pemerolehan kompetensi pragmatik anak. Faktor 
internal yang dikaji berkaitan dengan proses mental anak sebagai pembelajar bahasa, khususnya strategi pemerolehan yang digunakan anak untuk menghasilkan kompetensi pragmatik.Berkenaan dengan masukan beberapa gagasan yang penting adalah (1) adanya penyesuaian masukan (adjusted input) dari mitra tutur, yaitu penutur asli, orang dewasa, dan (2) adanya negosiasi makna, yaitu saling memahami maksud percakapan dengan cara saling mengadakan penyesuaian dan modifikasi dalam interaksi percakapan. Perlu diperhatikan adalah usaha anak untuk berinteraksi dengan orang dewasa berperan penting dalam proses pemerolehan kompetensi pragmatik. Ciri-ciri bahasa pengasuh yang berupa penyesuaian, modifikasi, dan negosiasi makna sangat membantu proses pemerolehan tersebut. Dengan kata lain penguasaan kompetensi pragmatik terjadi karena adanya kebutuhan untuk berkomunikasi dengan orang lain.

\section{Strategi Belajar}

Strategi belajar digambarkan sebagai sifat dan tingkah laku yang tidak teramati, atau langkah nyata yang dapat diamati (Huda, 1999). Sedangkan Oxford mendefinisikan strategi belajar sebagai tingkah laku atau tindakan yang dipakai oleh pembelajar agar pembelajaran bahasa lebih berhasil, terarah, dan menyenangkan. Pengertian ini lebih bersifat perbuatan yang dapat diamati walaupun dapat mencakup tindakan kognitif yang tidak teramati. Brown menekankan konsep strategi belajar sebagai tingkah laku yang tidak teramati di dalam diri pembelajar. Sedangkan menurut Stern, strategi belajar sebagai kecenderungan atau sifat-sifat umum dari pendekatan yang digunakan pembelajar bahasa kedua. Dengan demikian, strategi belajar sifatnya sangat personal, berbeda dari satu individu ke individu lainnya karena merupakan proses mental yang tidak nampak. Strategi pembelajaran hanya bisa diidentifikasikan melalui manifestasi perilakunya (Iskandarwassid, 2013: 2-32).

\section{Model Teoretik}

Pemerolehan bahasa anak usia dini dwibahasawan Jawa-Indonesia merupakan fenomena kebahasaan, fenomena sosial budaya, dan fenomena psikologis. Sejalan dengan hal tersebut, gambaran mengenai bentuk pemerolehan kompetensi pragmatik anak dwibahasawan Jawa-Indonesia dapat diidentifikasi melalui penggunaan aspek-aspek pragmatik anak dalam berinteraksi dengan mitra tuturnya. Kompetensi pragmatik BI anak diperoleh selama proses pemerolehan berlangsung dengan strategi tertentu. Strategi pemerolehan kompetensi pragmatik BI anak tampak pada proses pemilikan komponen-komponen bahasa berupa aspek-aspek pragmatik dalam struktur mental anak sehingga anak dapat menggunakan atau memilih tuturan yang sesuai untuk berbicara dengan mitra tutur tertentu untuk menyatakan maksud-maksud tertentu, yang ditandai dengan ciri-ciri tertentu. Strategi pemerolehan kompetensi pragmatik BI anak terealisasi pada tindak tutur yang dihasilkan dalam komunikasi. Pengkajian terhadap pemerolehan aspek tindak tutur ini didasarkan pada pandangan bahwa unit komunikasi bahasa bukan berupa simbol, kata, atau kalimat, melainkan berupa pemroduksian simbol, kata, atau kalimat yang terperformansi dalam tindak tutur.

Untuk mencapai tujuan pengkajian tersebut, ancangan teori yang digunakan adalah pragmatik dan psikolinguistik, khususnya pemerolehan bahasa. Teori pragmatik digunakan untuk memahami dan mengkaji bentuk-bentuk kompetensi pragmatik BI anak usia dini dwibahasawan Jawa-Indonesia yang ditunjukkan melalui penggunaan aspek-aspek pragmatik anak dalam 
berkomunikasi. Teori psikolinguistik digunakan untuk memahami dan mengkaji strategi permerolehan kompetensi pragmatik BI anak usia dini dwibahasawan Jawa-Indonesia. Teori pragmatik yang digunakan dalam penelitian ini didasarkan pada gagasan-gagasan yang dikemukakan oleh Lavinson (1986), terutama yang berkaitan dengan pengertian pragmatik dan pemilahan aspek-aspek kajian pragmatik. Bertolak dari teori tersebut peneliti mengidentifikasi, memahami, mengkaji, dan memerikan bentuk-bentuk pemerolehan kompetensi pragmatik BI anak.

Berdasarkan model kerja teori konstruksi kreatif, menurut Dulay, Burt, dan Krashen, 1982), proses konstruksi dalam pemerolehan bahasa dikendalikan oleh mekanisme kejiwaan yang bersifat bawaan atau kodrati yang dipandu oleh pemroses internal. Pemroses internal ini terdiri atas tiga komponen, yaitu filter, pengoranisasi, dan monitor. Pemroses internal berkaitan dengan variabel sekunder, yang meliputi lingkungan bahasa, kepribadian, umur, dan B1 pembelajar. Namun, tidak semua variabel sekunder tersebut berpengaruh terhadap semua komponen pemroses internal.

\section{METODE}

Penelitian atas tuturan anak usia dini dwibahasawan Jawa-Indonesia yang diujarkan dalam interaksi dengan mitra tutur, dan catatan lapangan tentang konteks komunikasi yang diperoleh dari hasil pengamatan peneliti di lapangan.Untuk mencapai tujuan penelitian, dalam penelitian ini digunakan pendekatan kualitatif yang didasarkan pada (1) objek yang dikaji fenomena penggunaan bahasa anak usia dini dwibahasawan Jawa-Indonesia dalam interaksi dengan mitra tutur dalam konteks alamiah berupa tuturan dalam komunikasi verbal anak usia dini dwibahasawan Jawa-Indonesia yang diperoleh melalui kegiatan komunikasi dalam kehidupan mereka sehari-hari, (2) peneliti sebagai instrumen kunci, dan (3) tujuan mengkaji fenomena pemerolehan kompetensi pragmatik BI anak usia dini dwibahasawan Jawa-Indonesia yang dilakukan secara induktif.

Subjek penelitian penutur bahasa anak usia dini dwibahasawan JawaIndonesia, interaksi verbal pada komunikasi dengan berbagai mitra tutur dapat diidentifikasi berdasarkan penggunaan tindak tutur dengan ciri-ciri tertentu. Subjek penelitian adalah lima anak usia dini, terdiri atas anak usia 2 sampai 4 tahun terpilih melalui kunjungan. Kelima subjek tersebut diambil berdasarkan studi lapangan dan kelayakan karakteristik yang ditetapkan, maka atas nama subjek (1) Aisya Syifa Alfinnurrohmah, usia 2 tahun 3 bulan 28 hari, dusun Boro RT 01/RW 05 Desa Tliskriyo, kecamatan Sanankulon Kabupaten Blitar, (2) Ayla Faezya Tarissa Ahmad, 3 tahun, RT 01/RW 05, dusun II Gaprang Kecamatan Kanigoro Kabupaten Blitar, (3) Hasbi Ash Shidiqi, usia 3 tahun 2 bulan, dusun Talok Garum Kabupaten Blitar, (4) Salma Rizki Amadia Hermawan, usia 3 tahun, desa Candirejo Kecamatan Ponggok Kabupaten Blitar, dan (5) Awalu Zein Hafitz Al Sidik, usia 2 tahun, dusun Sidomulyo RT 06/RW 09 desa Sukorejo Kecamatan Ponggok Kabupaten Blitar diambil sebagai subjek kajian penelitian di antara berbagai subjek kajian.

\section{Desain Penelitian}

Berdasarkan waktu yang digunakan untuk melakukan mengamati subjek, penelitian ini menggunakan desain/rancangan silang (cross sectional). Dengan 
cara ini peneliti tidak mengikuti subjek dalam waktu yang lama dalam periode tertentu, tetapi mengamati pada tahap tertentu proses pemerolehan bahasa subjek dalam waktu tertentu. Dalam hal ini peneliti mengamati pemerolehan kompetensi pragmatik subjek dengan usia beda, yaitu anak usia dini dwibahasawan JawaIndonesia usia antara 2 sampai 4 tahun pada suatu tahap tertentu.

\section{Teknik Pengumpulan Data}

Teknik pengumpulan data yang digunakan adalah teknik pengamatan (partisipasi maupun nonpartisipasi), difokuskan pada kegiatan anak usia dini dwibahasawan Jawa-Indonesia dalam melakukan interaksi verbal dengan mitra tutur. Teknik pengamatan dilengkapi dengan pencatatan lapangan dan perekaman. Perekaman data dilakukan untuk memperoleh data yang berupa tuturan bahasa anak usia dini dwibahasawan Jawa-Indonesia dengan berbagai mitra tutur. Data ini diperlukan untuk menjawab masalah penelitian, yaitu untuk mengkaji bentuk dan strategi pemerolehan kompetensi pragmatik BI anak usia dini dwibahasawan Jawa-Indonesia.

\section{Analisis Data}

Berbagai data pendukung penelitian dianalisis berdasarkan teknik analisis diskursif dengan tujuan untuk menerangkan suatu fenomena bahasa secara mendalam dengan memanfaatkan fakta kebahasaan tertentu yang menjadi sasaran penelitian. Peneliti dapat memiliki kesempatan yang leluasa untuk melakukan interpretasi terhadap rekaman percakapan yang diperoleh dari subjek. Alur kegiatan analisis yaitu seleksi data, pengkodean data, pengklasifikasian data, penyajian data, dan penarikan kesimpulan.

\section{HASIL}

Ditemukan (1) pola dominasi sosial-budaya dalam pemerolehan kompetensi pragmatik ber-BI anak usia usia dini di era revolusi digital dalam lingkungan keluarga enik Jawa, (2) strategi pemerolehan kompetensi pragmatik anak usia usia dini yang meliputi (a) strategi belajar, dan strategi komunikasi. Pola dominasi sosial-budaya dalam pemerolehan kompetensi pragmatik ber-BI anak usia dini terkai ketika subek kaian menggunakan bahasa secara berbeda untuk tujuan yang berbeda, hal ini tampak pada kajian bahwa subjek kajian meminta aturan sosial, meminta izin untuk mengekspresikan emosi, maupun membuat penilaian terhadap benda yang dijadikan bahan pembelajaran. Kajian lain tampak pada saat bahasa digunakan untuk bercanda, merajuk, atau meminta permintaan yang tidak langsung dalam percakpan atau dialog. Anak usia dini dapat terlibat dalam proses penyusunan tindak tutur/ujaran secara tepat terbatas ketika berkomunikasi dengan lawan tutur yang lebih tua/dewasa. Pemahaman terhadap apa yang dibutuhkan ini merupakan implementasi sosio-budaya, tumbuhnya kesadaran metalinguistik bahwa bahasa dapat digunakan untuk mencapai tujuan tertentu (merespon pertanyaan, berbagi perhatian di antara keduanya terhadap topik wicara).

Sikap ini menjadi tindak pro-aktif keterlibatan faktor lingkungan bahasa dalam proses pemerolehan kompetensi pragmatik anak. Terbukti bahwa dari kelima subjek tersebut: dalam melakukan pembelajaran maupun komunikasi penutur melakukan banyak memberikan pembelajaran ialah SY, orang tua tersebut aktif dalam memberikan kosa kata baru, AY juga memberikan pembelajaran namun penutur lebih memberikan tindak tutur untuk belajar sendiri 
namun tetap terarahkan oleh si penutur, HB dalam melakukan komunikasi antara penutur sangat merespon dan dapat mengikuti penutur namun saat tindak tutur mengeluarkan kata-kata yang cedal penutur malah mengikuti tindak tutur melakukan kata yang cedal, AW adalah tindak tutur penurut namun jika keinginanya tidak dituruti maka dia akan menangis dan merengek untuk mendapatkan sesuatu, dan SR kurang memiliki kosakata karena penutur kurang memberikan kosa kata baru.

Dukungan lingkungan terhadap perkembangan bahasa hadir saat pola interaksi ditemukan dalam percakapan, seperti mendengar, merespon apa yang telah diucapkan, mengulangi untuk klarifikasi dan mengajukan beberapa pernyataan yang dilakukan subek anak usia dini. Peran orang dewasa sebagai lingkungan bahasa dalam proses komunikasi sangatlah penting untuk mendukung perkembangan bahasa pragmatik anak. Hal ini berdasarkan kajian bahwa anak sebagai komunikator pemula, lawan tutur lingkungan bahasa menjadi pembantu kedua dalam komunikasi yang mampu menciptakan kondisi efektif dalam percakapan yang pada dasarnya semakin banyak kosa kata yang di dapat anak semakin baik tindak tutur anak dalam kemampuan pragmatiknya dalam mencapai tujuan tindak tutur. Perbedaan terlihat pada kajian paparan data bahwa apa yang dilakukan sendiri oleh anak dan dengan mediasi orang dewasa atau teman sebaya yang kebih mampu menunjukkan tingkat kemampuan kompetensi yang berbeda. Terlihat subjek SF dan AY memiliki kompetensi pragmatik lebih tinggi dari subjek yang lain.

Pola ujaran yang ditujukan kepada anak terlihat dari hasil kajian perekaman terhadap subjek, bagaimana bahasa spesifik yang dipakai lawan tutur dewasa berfungsi mempertinggi perkembangan bahasa anak. Penanda pola ini terdata atas hasil kajian perekaman yang menunjukkan ujaran lawan tutur dewasa menggunkan ujaran yang pendek dan dibentuk dengan baik, ujaran dimulai dengan permulaan yang sedikit keliru seperti pada saat berbincang dengan sesama lawan tutur dewasa, penggunaan beberapa kalimat yang cukup kompleks, nada yang digunakan lebih tinggi, intonasi sedikit dilebihkan, diulang-ulang dalam bagian-bagian tertentu, kadar ujaran atau tempo lebih pelan daripada berbicara pada teman sebaya, ujaran mengarah pada konteks secara langsung, dan ujaran lebih mengarah untuk mendorong anak untuk berpartisipasi serta mengklarifikasi respon ujaran anak. Pola ini terlihat pada subjek HB dengan mitra tutur sang kakek dan peneliti dengan latar tempat di sawah (DLTV3HB), selanjutnya subek SY pada data DLTV2SY, DLTV3HB dan DLTV3SY.

Pola pemetaan verbal terkaji pada situasi perekaman yang mana terjadi ketika lawan tutur dewasa memberikan gambaran atau penjelasan sebuah benda atau tindakan dalam berinteraksi. Lawan tutur dewasa memberikan penjelasan verbal tentang apa yang dibicarakan, dialami, atau dilihat. Hal ini terdata pada pola perkembangan pragmatik SY, AW, HB, SR dengan mitra tutur. Dalam proses perkembangan bahasa keempat subjek tersebut lebih dominan mitra tutur dewasa menggunakan bahasa untuk menyesuaikan situasi, menyajikan gambaran lanjutan kepada anak yang berfungsi mengidentifikasi terhadap situasi yang terjadi. Pola pemetaan verbal ini dapat dikaji terpaparkan pada perekaman subjek SR dengan latar belakang ruang makan, setelah pulang dari membeli lauk pauk (kentaki) DLTV3SR, selanjutnya terkaji pada audio 1 AW (DLTV1AW), percakapan antara AW dengan kakak perempuannya. 
Pola mengajukan pertanyaan juga terlihat pada perekaman subjek SY dan AW. Pola ini berkarkater mitar tutur dewasa mengajukan pertanyaan kepada anak, yang mana pertanyaan diajukan tersebut juga sering dijawab sendiri oleh lawan tutur dewasa. Pola interaksi mengajukan pertanyaan terdata pada subjek SY dengan mitra tutur pada audio 1, 2, dan 3. Mitra tutur (nenek SY) seperti biasa sebagai pengasuh membuka sebuah buku gambar, tempat di dalam kamar tidur sekaligus biasa digunakan untuk belajar bagi SY. Setelah mereka duduk di tempat tidur, nenek SY mengajukan pertanyaan terkait nama-nama sesuai dengan gambar yang ditunjuk.

Pemerolehan bahasa anak usia dini dwibahasawan Jawa-Indonesia merupakan fenomena kebahasaan, fenomena sosial budaya, dan fenomena psikologis. Sejalan dengan hal tersebut, gambaran mengenai bentuk pemerolehan kompetensi pragmatik anak dwibahasawan Jawa-Indonesia dapat diidentifikasi melalui penggunaan aspek-aspek pragmatik anak dalam berinteraksi dengan mitra tuturnya. Kompetensi pragmatik BI anak diperoleh selama proses pemerolehan berlangsung dengan strategi tertentu. Strategi pemerolehan kompetensi pragmatik BI anak tampak pada proses pemilikan komponen-komponen bahasa berupa aspek-aspek pragmatik dalam struktur mental anak sehingga anak dapat menggunakan atau memilih tuturan yang sesuai untuk berbicara dengan mitra tutur tertentu untuk menyatakan maksud-maksud tertentu, yang ditandai dengan ciri-ciri tertentu. Strategi pemerolehan kompetensi pragmatik BI anak terealisasi pada tindak tutur yang dihasilkan dalam komunikasi. Pengkajian terhadap pemerolehan aspek tindak tutur ini didasarkan pada pandangan bahwa unit komunikasi bahasa bukan berupa simbol, kata, atau kalimat, melainkan berupa pemroduksian simbol, kata, atau kalimat yang terperformansi dalam tindak tutur.

Pemerolehan bahasa anak usia dini dwibahasawan Jawa-Indonesia merupakan fenomena kebahasaan, fenomena sosial budaya, dan fenomena psikologis. Gambaran mengenai bentuk pemerolehan kompetensi pragmatik anak dwibahasawan Jawa-Indonesia diidentifikasi melalui penggunaan aspek-aspek pragmatik anak usia dini dalam berinteraksi dengan mitra tuturnya. Kompetensi pragmatik BI anak diperoleh selama proses pemerolehan berlangsung dengan strategi tertentu. Strategi pemerolehan kompetensi pragmatik BI anak tampak pada proses pemilikan komponen-komponen bahasa berupa aspek-aspek pragmatik dalam struktur mental anak sehingga anak dapat menggunakan atau memilih tuturan yang sesuai untuk berbicara dengan mitra tutur tertentu untuk menyatakan maksud-maksud tertentu, yang ditandai dengan ciri-ciri tertentu. Strategi pemerolehan kompetensi pragmatik BI anak usia dini ini terealisasi pada tindak tutur yang dihasilkan dalam komunikasi. Perubahan mental intelektual ini terlihat pada anak kajian dari 5 subjek anak usia dini dalam mengubah tingkah lakunya, baik dalam berpikir, bersikap, dan berbuat. Variasi perubahan terkaji melalui proses tingkah laku atau penampilan anak kajian dalam mempelajari bahasa bersama mitra tutur dalam lingkungan belajarnya (berkomunikasi).

Strategi belajar kajian pragmatik ini merujuk pada interakasi subjek kajian anak usia dini dalam berinteraksi dengan mitra tutur, menekankan pada aspek kognitif yang bersifat personal, berbeda dari satu subjek didik dengan subjek didik yang lain. Hal ini terjadi karena proses mental anak usia dini yang tidak tampak dan faktor-faktor dalam diri subjek kajian seperti cara belajar yang digunakakan menjadi faktor penyebab baik dari diri subjek maupun dari lingkungan. Strategi 
belajar sosial berkaitan dengan upaya subjek kajian mendapat kesempatan berbahasa sebanyak mungkin untuk meningkatkan interaksi dengan mitra tutur, termasuk bagaimana cara mengajukan permintaan, pertanyaan, memberikan penjelasan atau klarifikasi.

Faktor-faktor penyebab keberhasilan strategi belajar terkaji karena dipengaruhi oleh faktor perkembangan usia, tingkat penguasaan bahasa, kedwibahasaan, kepribadian, masukan dan interaksi. Fungsi strategi belajar tersebut ketika anak berusaha menguasai bentuk-bentuk tuturan untuk menyatakan maksud tertentu kepada mitra tutur, untuk menyatakan fakta, pertanyaan, permintaan, nasihat, terima kasih, salam/doa, perintah, permohonan.

Strategi belajar pada proses akulturasi pemerolehan kompetensi pragmatik anak usia dini terlihat pada data temuan subjek (SY), (HB), (AW), (SR), dan (AY) dengan berbagai faktor penyebab dan kefungsian pragmatis yang dilakukan untuk menyatakan berbagai maksud kepada mitra tutur. Perbedaan latar belakang dari masing-masing subjek kajian seperti faktor keadaan lingkungan sosial, budaya, gaya belajar (pola), perkembangan usia, tingkat penguasaan berbahasa, kepribadian, serta eksistensi masukan dan interaksi memberikan keberbedaan dalam akulturasi pemerolehan pragmatiknya. Tampak kajian pada percakapan antara subjek anak usia dini SY dan Uti serta Ummi (ibunya).

Perkembangan kompetensi pragmatik bahasa anak berkaitan dengan apa yang dipelajari, kapan dipelajarinya, dan faktor-faktor apa yang mempengaruhi proses perkembangannya. Strtegi belajar berkaitan dengan upaya pembelajara anak usia dini di lingkungan kedwibahasaaan Jawa-Indonesia ini mendapatkan kesempatan berbahasa sebanyak mungkin dalam meningkatkan interaksi dengan mitra tutur (dewasa) dalam meningkatkan motivasi belajar berbahasa. Beberapa faktor pemengaruh peningkatan perkembangan pemerolehan bahasa pragmtik terkaji pada permasalahan tingkat penguasaan bahasa, kedwibahasaan anak, sifat kepribadian yang dimiliki subjek kajian, serta masukan mitra tutur dan interaksi maksimal ketika bersosial. Kajian terdeteksi pada pola bagaimana anak berkomunikasi bersama mitra tutur dengan strategi sosial mengajukan pertanyaan atau permintaan klarifikasi terhadap hambatan komunikasi, memberikan penjelasan responsi-timbal balik dengan mitra tutur (dewasa).

Strategi komunikasi yang terkaji tipe-tipe strategi komunikasi strategi penggunaan bentuk nonverbal. Dalam kajian ditemukan strategi komunikasi dalam bentuk penggunaan isyarat dan gerakan, penggunaan gerakan saja, penggunaan gambar, dan penggunaan lagu. Dalam bentuk lain juga ditemukan strategi penggunaan bentuk verbal. Pada temuan strategi ini terkaji tipe penggunaan bentuk verbal (pemaparan tuturan), pengungkapan isi tuturan (penajaman maksud, pengalihan topik, pemutusan pesan). Faktor penyebab terletak pada pengaruh perkembangan usia anak menjadi penanda khusus, tingkat penguasaan bahasa, kedwibahasaan, kepribadian anak, situasi belajar dengan mitra tutur, dan tujuan komunikasi menjadi penentu kompetensi pragmatik. Fungsi strategi komunikasi komunikasi pragmatik anak usia dini terevaluasi pada maksud dan tujuan pada proses menyatakan menyatakan fakta atau keadaan yang diamati anak, pertanyaan karena tidak memahami objek, permintaan terhadap objek lain, penolakan terhadap pemahaman yang tidak sesuai dengan keinginan anak, tidak suka, berpendapat, alasan, perintah, keluhan, meminta maaf, marah, dan larangan. 


\section{KESIMPULAN}

Strategi belajar anak usia dini merupakan pemrosesan, penyimpanan, dan pengambilan masukan pemerolehan bahasa (pragmatik), merujuk pada interkasi dalam berinteraksi dengan mitra tutur. Strategi belajar anak usia dini ditemukan kajian terkait (1) tipe-tipe, (2) faktor penyebab, dan (3) fungsi. Tipe-tipe strategi belajar merujuk pada perilaku (1) strategi kognitif terkait peniruan, pengulangan, penggunaan pola, perbaikan tuturan, penerjemahan; dan (2) strategi sosial yang terkait pada kajian permintaan klarifikasi dan pertanyaan responsi-timbal balik.

Strategi belajar kompetensi pragmatik anak usia dini etnik Jawa ini lebih menekankan pada aspek kognitif yang bersifat personal, satu subjek didik dengan subjek didik yang lain. Hal ini terjadi karena proses mental yang tidak tampak dan faktor-faktor dalam diri subjek kajian seperti cara belajar yang digunakakan faktor penyebab baik dari diri subjek maupun dari lingkungan. Strategi belajar sosial berkaitan dengan upaya subjek kajian mendapat kesempatan berbahasa sebanyak mungkin untuk meningkatkan interaksi dengan mitra tutur dalam usaha meningkatkan motivasi belajar. Termasuk di sini bagaimana cara mengajukan permintaan, pertanyaan, memberikan penjelasan atau klarifikasi.

Faktor-faktor strategi belajar dipengaruhi oleh faktor perkembangan usia, tingkat penguasaan bahasa, kedwibahasaan, kepribadian, masukan dan interaksi. Fungsi strategi belajar pada dasarnya menguasai bentuk-bentuk tuturan untuk menyatakan maksud kepada mitra tutur, yaitu menyatakan fakta, pertanyaan, permintaan, nasihat, terima kasih, salam/doa, perintah, permohonan.Strategi komunikasi ini terkait (a) strategi penggunaan bentuk nonverbal (penggunaan isyarat dan gerakan, penggunaan gerakan saja, penggunaan gambar, dan penggunaan lagu; (b) strategi penggunaan bentuk verbal, (pemaparan tuturan), pengungkapan isi tuturan (penajaman maksud, pengalihan topik, pemutusan pesan). Faktor pengaruh perkembangan usia dini terletak pada tingkat penguasaan bahasa, kedwibahasaan, kepribadian, situasi belajar, dan tujuan komunikasi. Fungsi strategi komunikasi terjadi karena keterbatasan penguasaan kosakata sebagai khasanah perkembangan bahasa sebagai komunikasi pragmatik anak untuk menyatakan berbagai maksud, seperti menyatakan fakta, pertanyaan, permintaan, penolakan, tidak suka, berpendapat, alasan, perintah, keluhan, meminta maaf, marah, larangan.

\section{SARAN}

Hasil kajian ini diharapkan memperluas wawasan pendidik terkait proses pemerolehan kompetensi pragmatik anak sehingga dapat memaksimalkan perannya untuk menciptakan lingkungan yang kondusif bagi perkembangan kompetensi pragmatik anak didik. Secara teoritis hasil kajian ini berimplikasi terhadap proses pengembangan teori strategi pemerolehan bahasa, terutama pada teori strategi belajar dan strategi komunikasi khususnya pencapaian pemerolehan kompetensi pragmatik anak didik, maka diharapkan penelitian ini memberikan kontribusi dalam khasanah wawasan teori kebahasaan khususnya dalam studi kajian psikolinguistik (pemerolehan bahasa), strategi belajar, strategi komuniaksi, pragmatik dan dapat menjadi acuan bagi penelitian-penelitian sejenis yang lain secara mendalam. Secara praktis hasil kajian ditemukan adanya pengaruh akulturasi lingkungan dan budaya terhadap proses pemerolehan kompetensi pragmatik. Kajian ini dapat memberikan sumbangan pengetahuan bagi orang tua, 
praktisi pendidikan, peneliti dan para pendidik atau pengasuh pra sekolah/usia dini agar dalam membelajarkan anak didik atau peserta didiknya memahami dan melakukan strategi-strategi tuturan yang lebih mudah dicerna selanjutnya dipahami oleh peserta didik/anak didik.

\section{DAFTAR PUSTAKA}

Alwasilah, A. Chaedar. 2011. Beberapa Mahzab dan Dikotomi Teori Linduistik. Bandung: Angkassa.

Baradja, M. F. 1990. Perkembangan Teori Pemerolehan Bahasa Kedua dalam kaitannya dengan Proses Belajar-Mengajar. Pidato Pengukuhan Guru Besar. IKIP MALANG.

Cumings, Louise. 2007. Pragmatik, Sebuah Perspektif Multidisipliner. Yogyakarta: Pustaka Pelajar.

Dardjowidjojo. S. 1987. Linguistik: Teori \& Terapan. Prosiding dari Simposium Linguistik 1985 Lustrum V Unika Atma Jaya.

Dardjowidjojo. S. 2000. ECHA Kisah Pemerolehan Bahasa Anak Indonesia. Jakarta: Grasindo.

Dardjowidjojo. S., 2010. Psikolinguistik: Pengantar Pemahaman Bahasa Manusia. Jakarta: Yayasan Obor Indonesia.

Dardjowidjojo. S., 2012. Psiko-Linguistik. Penghantar Pemahaman Bahasa Manusia. Jakarta: Yayasa Pustaka Obor Indonesia.

Goode, W.J. 2002. Sosiologi Keluarga. Jakarta: Bumi Aksara.

Iskandarwassid. 2013. Strategi Pembelajaran Bahasa. Bandung: PT Remaja Rosdakarya.

Mbete, A. M. 2004. Linguistik Kebudayaan: Rintisan Konsep dan Beberapa Aspek Kajiannya. Dalam Bahasa dalam Perspektif Kebudayaan. Denpasar: Universitas Udayana.

Menno, S. dan M. Alwi. 1994. Antropologi Perkotaan. Jakarta: RajaGrafindo Persada.

Otto, Beverly. 2015. Perkembangan Bahasa Pada Anak Usia Dini. Jakarta: Prenadamedia Group.

Pateda, Mansoer. 1991. Linguistik Terapan.Bandung: Nusa Indah.

Rani, Abdul, dkk. 2004. Analisis Wacana. Sebuah Kajian Bahasa dalam Pemakaian. Malang: Bayyumedia Publishing.

Saryono, Djoko.2010. Pemerolehan Bahasa. Malang: Nasa Media.

Sumarsono. 2013. Sosiolinguistik. Yogyakarta: Pustaka Belajar.

Suparno. 1996. Penggunaan BJ dalam Keluarga Muda Etnis Jawa. Dalam Kartomihardjo, S. (Ed). Konggres Bahasa Jawa II 1996. Surabaya: Pemerintah Propinsi Daerah Tk. I Malang.

Tarigan, Henry Guntur. 2009. Psikolinguistik. Bandung: Angkasa.

Trianto. 2011. Model-Model Pembelajaran Inovatif Berorientasi Konstruktif. Konsep, Landasan Teoritis-Praktis dan Implementasinya. Jakarta: Prestasi Pustaka.

Wahab, A. 2002. Kealpaan Terhadap Penghormatan dan Pemeliharaan Bahasa Daerah Pengemban Kebudayaan Nasional. Makalah disajikan dalam Konggres Linguistik Nasional (KLN) 2002.

Wiryotinoyo, M. 1996. Implikatur Percakapan Anak Usia SD. Disertasi tidak diterbitkan. Program Studi Pendidikan BI. PPS. IKIP MALANG. 